\title{
Kontribusi Sektor Pertekstilan dalam Ekspor Nasional
}

Oleh Edy Suandl Hamid

\begin{tabular}{|l|l|}
\hline & $\begin{array}{l}\text { Edy SuandI HamId, adalah dosen negeri yang } \\
\text { dipekerjakan pada Fakultas Ekonomi Universitas Islam } \\
\text { Indonesia, disamping juga sebagai staf peneliti pada } \\
\text { PusatPenelitian Pembangunan Pedesaandan Kawasan } \\
\text { (P3PK) UGM dan Sekretaris Ikatan Sarjana Ekonomi } \\
\text { Indonesia DIY. Lahir di Tanjung Enim 11 Desember } \\
\text { 1957, dan menyelesaikan studi dari FE UGM jurusan }\end{array}$ \\
$\begin{array}{l}\text { ilmu ekonomi dan studi pembangunan (Umum), April } \\
\text { 1983 S1 serta S2 dari Faculty of Economic Thammasat University, Bangkok 1990. }\end{array}$ \\
Pernah menjadi wartawan dan redaksi ekonomi harian Kedaulatan Rakyat, serta \\
Pimpinan Redaksi majalah Equilibrium (FE UGM). Kini aktif dalam kegiatan \\
penelitian yarig menyangkut masalah pedesaan. Menulis buku Pengantar Teori \\
Perilaku Konsumen (bersama Drs. Effendi Ari, 1985), menyunting buku redit \\
Pedesaandilndonesia(bersamaProf. Mubyarto, 1986) danMeningkatkan Efisiensi \\
Nasional (bersama Prof. Mubyarto, 1987).
\end{tabular}

\section{Pengantar}

Sektor pertekstilan Indonesia termasuk sektor yang. paling menonjol perkembangannya dalam perekonomian nasional. Perkembangan ini dapat dilihat darikontribusinyaatas sumbangan sektoral padaPDB, khususnya dalam sektor industri; manufaktur nonmigas,' penciptaan kesempatan kerja maupun dalam menghemat dan menumbangkan devisa bagiperekonomiannasional.Dalam tulisan ini tidak akan membahas secara menyelurüh aspek-aspek yang berkaitan dengan peran industri tekstil nasional tersebut, melainkan hanya dari sisi perannya dalam ekspor Indonesia, yang sekarang ini sudah menempati peringkat terbesar dari ekspor komoditi nonmigas nasional.

Pendahuluan

Ekspornonmigas saat ini memegang pèranan yang sangat penting bagi perekonomian Indonesia. Peran ini mulai menunjukkan peningkatan yang pesat sejak pertengahan tahun 1980-an. Keadaan ini terjadi karena pemerintah semakin menyadari bahwa ketergantungan yang tinggi pada ekspor minyak dan gas bumi (migas) akan sangat mengganggu kelancaran pembangunan näsional secara keseluruhan. Ini disebabkan di samping harga migas di pasarduniasangat fluktuatif, juga karena cadangan migas Indonesia terbatas jumlahnya dan diperkirakan dalam jangka 10-15 tahun lagi Indonesia sudah tidak bisa mengekspor migas, bahkan sebaliknya harus membeli dari pasar internasional untuk memenuhi kebutuhan domestik.

Dengan kondisi seperti itu tidak mengherankan -kalau kebijakan perdagangan luar negeri Indonesia, 
khususnya untuk ekspor, ditekankan pada peningkatan ekspor komoditi nonmigas tersebut. Hasilnya, disamping masih terdapat berbagai kelemahan dan hambatan di sana-sini, memang cukup menggembirakan. Sejak tahun 1987, pertamakali tercatat dalam sejarah Orde Baru, nilai ekspor nonmigas sudah melebihi ekspor migas.

Namun demikian sebelum ekspor nonmigas secarakeseluruhan dipacu, sektor pertekstilan sebenamya sudah lebih dulu melangkah dalam memasuki pasar intemasional. Sektor pertekstilan sejak awal Orde Baru memang sudah dikembangkan sebagai salah satu sektor industri substitusi impor. Hal ini terjadi karena sejak masa sebelumnya ketergantungan pada tekstil dan produk tekstil lainnya dari luar negeri sangat tinggi. Padahal produk tekstil merupakan salah satu kebutuhan primer masyarakat yang dari waktu ke waktu meningkat terus kebutuhannya. Akibatnya sektor ini menghabiskan devisa yang cukup besar untuk membiayai impornya.

Sektorpertekstilan ini dikembangkan karena beberapa alasan. Pertama, pasar yang sudah pasti di dalam negeri yang jumlahnya cukup besar bertambah dari tahun ke tahun. Kedua, teknologi yang digunakan tidak terlalu tinggi, sehingga memungkinkan bagi Indonesia untuk cepat menggunakan teknologi yang ada. Ketiga, sektor ini relatif padat karya, sehingga sesuai dengan kondisi ketenagakerjaan di tanah airyang masih surpluss tenaga kerja. Surplus tenaga kerja ini pula yang menyebabkan ùpah buruh menjadi múrah dan dianggap sebagai salah satu "keunggulan" komparatif sektor pertekstilan dan sektorindustri padat karya lainnya.

Dikaitkan dengan sasaran untuk menggantikan impor, maka ISI pada sektor perteksilan ini dapat dikatakan telah mencapai sukses yang besar. Barang tekstil yang tadinya diimporumumnya kini sudah bisa dipenuhi dari.produksi dalam negeri. Impor yang terjadi jumlahnya tidaklah terlalu significant, dan umumnya karena tuntutan demonstration effect atau bukan karena tuntutan keharusan. Perkembangan lebih lanjut bahkan sektor pertekstilan bukan saja bisa memenuhi kebutuhan akan tekstil dalam negeri, melainkan juga menjadi" primadona ekspor dari sektor nonmigas kita. Ini jika dilihat dari hasil produk akhimya. Namun demikian jika dilihat proses secara keseluruhan, maka sebenarnya sektor pertekstilan ini juga masih mengandung kelemahan, yakni dalam hal teknologi yang masih impor maupun ketergantungan bahan baku impor yang juga masih sangat besar.

\section{Perkembangan Umum}

Jika kita menatap perkembangan industri secara keseluruhan, maka di Indonesia saat ini sudah terjadi transformasi struktural, khususnya jika dilihat sumbangan sektoral atas PDB. (Produk Domestik Bruto). Sektor pertanian yang sejak dulu (sejak adanya bumi Indonesia) menjadi sektor penyumbang terbesar atas PDB, tahun 1991 sudah digeser oleh sektor industri. Perkembangan sektor industri dan pertanian serta kontribusinya atas PDB selama tiga tahun pertama Pelita III dapat dilihat pada Tabel berikut ini (Tabel)

Tabel 1

Pertumbuhan dan Kontrubsi Sektor

Industri dan Pertanian 1089-1991

\begin{tabular}{|lllll|}
\hline & \multicolumn{2}{l}{ Laju pertunbuhan (\%) } & \multicolumn{3}{c|}{ Sumbangan terhadap,PDB } \\
\cline { 2 - 5 } Tahun & Pertanian & lndustri & Pertanian & Industri \\
\hline 1989 & 3,12 & 11,57 & 20,58 & 18,48 \\
1990 & 2,51 & 12,80 & 21,52 & 20,32 \\
1991 & 1,03 & 11,03 & 19,60 & 22,2 \\
\hline
\end{tabular}


Meningkatnya kontribusí sektor industri (di dalamnya termasuk industri migas) atas PDB tersebut terjadi karena laju pertumbuhannya yang relatif tinggi, terutama jika dibandingkan dengan sektor pertanian dan pertumbuhan ekonomi secara keseluruhan. Sëlama Pelita I pertumbuhan sektor ini rata-rata $13,0 \%$ per tahun, dan selama Pelita II, Pelita III dan Pelita IV masing-masing adalah $13,7 \%$ dan $13,2 \%$. Perkembangan ini memang tidak bisa dilepaskan dari berbagai kebijakan pemerintah yang sejak awal PJPT I sudah mencanangkan untuk merubah struktur ekonomi nasional yang terlalu terkonsentrasi pada sektor agraris untuk lebih diarahkan pada sektor industri. Kebijakan tersebut pada awalnya antara lain berupa perlindungan (proteksi) pada berbagai cabang industri, dan kemudian dilanjuti dengan berbagai kebijakan deregulasi, debikrokratisasi, sehingga tercipta iklim yang relatif kondusif bagi investor di sektor ini (Pidato Pertanggungjawaban Presiden, 1 Maret 1993).

Dalam hal ekspor, maka peran sektor industri juga kian meningkat. Tahun 1984 eksporhasil industri baru mencapai $19,32 \%$ dari total ekspor Indonesia. Namun tahun 1991 angka ini sudah mencapai $52,80 \%$. Sedangkan jika dilihat dari' porsinya terhadap total ekspor nomigas sendiri, ekspor industri juga meningkat perannya dari 72,05\%(1984)menjadi 84,32\%(1991).

Hal yang sama juga terjadi dalam penyerapan tenaga kerja, walaupun masih belum seperti yang diharapkan. Tahun 1984 tenaga kerja di sektor industri baru 335.658 orang. Angka ini juga meningkat menjadi 3.038.241 pada tahun 1991.

Perkembangan sektor industri ini tidak bisa dilepaskan dari dukungan sektor industri tekstil yang berkembang sangat pesat dalam kurun waktu yang sama lihat Tabel). Produksi tekstillembaran(termasuk rajut), misalnya, produk tahun 1968 baru 316 juta meter. Tahun 1992/1993 diperkirakan meningkat menjadi 5564 juta ton atau naik 17,5 kali lipat dalam tempo 24 tahun: Hal yang sama juga terjadi dengan benang tenun yang meningkat dari 130 ribu bal (1868) menjadi 4474 bal (1992/1993) atau naik 34,4 kali lipat.

Tabel 2

Produksi Industri Tekstil 1968 - 1992/1993

\begin{tabular}{|c|c|c|c|c|}
\hline Jenis barang & 1968 & $1987 / 1988$ & $1988 / 1989$ & $1992 / 1993^{*}$ \\
\hline 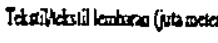 & j) 316 & 2925.6 & 3503,0 & 5564,0 \\
\hline benzng lenm (ibu lon) & 130 & 2275,7 & 27123 & 4474,0 \\
\hline pakzian jadi (juta losin) & 33,7 & 39,1 & 72,0 & \\
\hline sera! (ribu lon) & 139.7 & 160,2 & 210,0 & \\
\hline zat warna késtil (10a) & 1550 & 2080 & 6500 & \\
\hline
\end{tabular}

Dari Tabel di atas dapat diketahui 'bahwa produksi kedua jenis komoditi tekstil tersebut masing-masing meningkat $82,6 \%$ dan $81,9 \%$ dibandingkan dengan produksi tahun $1987 / 1988$. Perkembangan yang sama juga terjadi dengan industri pakaian jadi, yang saat ini cukup disegani di pasar internasional. Industri ini mulai terlihat perkembangannya sejak Repelita III. Pertumbuhan produksinya sejak akhir Repelita IV hingga tahun keempat Repelita $\mathrm{V}$ rata-rata mencapai $16,4 \%$ per. tahun. Perkembangan produksi ini diperkirakan akan terus meningkat, terutama jika dayasaing komoditi ini bisa terus ditingkatkan untuk memanfaatkan pasar dunia yang sangat potensial.

\section{Ketergantungan Impor}

Salah satu kelemahan industri tekstil 
Edy Suandi Hamid, Kontribusi Sektor Pertekstilan

kita adalah masih sangat tergantungnya pada bahan baku dari luar, khususnya untuk kapas atau serat alam. Untuk itu di dalam negeri dikembangkan pula industri serat buatan sebagai bahan baku benang yang dapat menggantikan serat alam tersebut. Produksi industri serat buatan tahun 1983/ 1984 baru 90,5 ribu ton menjadi 210 ribu ton pada tahun 1992/1993 atau meningkat sekitar 120\%. Angka-angka perkembangan produksi bahan baku tekstil ini memberikan indikasi bahwa sektor perteksilan sudah semakin besar kontribusinya dalam produksi sektor industri khususnya dań struktur PDB Indonesia umumnya.

Namun perlu dicatat bahwa bagaimanapun sebagian bahan baku industri tekstil ini masih sangat tergantung pada impor. Untuk itu sudah ada usaha dari industri ini juga untuk mengembangkan industri substitusi atas bahañ baku impor. Penurunanketergantungan pada bahan baku impor ini sangat penting agar industri tersebut semakin kokoh dan tidak terialu dipengaruhi perkembangan eksternal. Sebagai gambaran ketergantungan pada bahan baku impor ini dapat dilihat misalnya dari impor serat kapas (cotton fibres) dan serta buatan pintal, yang selama tahun 1991 masing-masing $353.559,6$ ton dan $79.075,1$ ton atau masing-masing menghabiskan devisa sebanyak USS $\$ 634.348,5$ ribu dan $119.761,1$ ribu atau sekitar Rp 1,6 trilyun atau hampir sebanyak 9 kali lipat lebih besar dari dana Inpres Pembangunan Desa yang dikeluarkan pemerintah dalam tahun 1990,1991 yang sebesar Rp 180,6 milyar. Ini belum termasuk impor mesin-mesin tekstil, yang bersama-sama dengan impor mesin untuk pengolahan kulit pada tahun 1991 sudah mencapai US $\$ 1654.778,5$ ribu atau sekitar $R p \cdot 3,5$ trilyun (Data: lihat Statistik Perdagangan, BPS,-'September
1992) dan Nota Keuangan 1993/1994).

Dari data impor bahan baku dan barang modal ini sebenarnya menggambarkan bahwa industri tekstilkita belum terlalu kokoh. Goncangan akan sangat mungkin terjadi kalau supply akan bahan baku dan barang modal tersebut terhambat. Kelangkaan ataupun friksi dari bahan baku ini akan sangat mempengaruhi produksi dan biayanya .-- sehingga juga mempengaruhi dayasaingnya--dariproduk tekstil tersebut.

Ketergantungan pada impor ini merupakan salah satu masalah dan tantangan yang harus dijawab oleh dunia perteksilan Indonesia. Sudah beberapa kali kenaikan bahan baku impor ini menggoncang dunia perteksilan di tanah air, yang berakibat pada kekhawatiran akan merosotnya industri ini. Sekarang ini industri tekstil kita juga banyak yang sudah harus melakukan restrukturisasi atas mesinmesinnya yang sudah tua. Sebagai gambaran, saat ini diperkirakan $30-40 \%$. mesin-mesin pada industri tekstil sudah harus diganti (Bisnis Indonesia, 20 Agustus 1993). Sepanjang ketergantungan teknologis ini masih seperti sekarang, maka mau tak mau mesin-mesin-tersebut harus dibeli dari luar, dengan harga dan persyaratan yang ditentukan dari pihak luar tersebut.

\section{Perkembangan Ekspor}

Sebagaimana disinggung di atas, inglustri.tekstil saat ini sudah menjadi salah satu industri andalan bagi komoditi ekspor nasional. Sejak tahun 1991 industri tekstil dan pakaian jadi sudah menggeser kedudukan ekspor kayu lapis yang selama enam tahun menempati posisi sebagai penyumbang devisa terbanyak dalam ekspor nonmigas Indonesia. Secara garis 
besarperingkat penghasil devisa Indonesia dalam tahun 1989-1991 dapat dilihat pada Tabel berikut ini.

Jika dilihat kontribusinya, maka angka sementara 1992/1993 menunjukkan bahwa kontribusi ekspor tekstil atas ekspor nonmigas secara keseluruhan sudah mencapai $24,06 \%$. Kontribusi ini jauh meningkat dibandingkan tahun 1978/1979 yang waktu itu hanya memberikan andiI sebanyak $0,21 \%$ dari ekspor nonmigas Indonesia waktu itu. nilai eksporminyak bumi ataupun gas alam yang sampai saat sekarang masih menempati urutan teratas dalam menyumbang devisa pada struktur ekspor Indonesia. Ini dapat terjadi karena jika diamati kecenderungan lima tahun terakhir ini sumbangan pada kenaikan ekspor pakaian jadi, tekstil dan benang tenun juga menempati posisi kenaikan yang tertinggi, yakni secara keseluruhan sebesar $38 \%$. Untuk industri pakaian jadi sumbangannya terhadap kenaikan total ekspor nonmigas

Tabel 3

Urutan Penghasilan Devisa Indonesia (Juta US\$).

\begin{tabular}{|c|c|c|c|}
\hline No. Kornoditi & 1989 & 1990 & 1991 \\
\hline 1. Minyak Bumi & 6.060 .30 & 9.946 .90 & 5.695 .90 \\
\hline 2. Gas alam & 2.168 .40 & 3.551:50 & 4.180 .50 \\
\hline 3. Kayu & 3.494 .00 & 2.725 .00 & 3.659 .79 \\
\hline 4. Karet & .1 .218 .60 & 1.200 .70 & 981.16 \\
\hline 5. Kopi & 4.815 .80 & 553.20 & 3561.16 \\
\hline 6. Pariwisata & 1.218 .00 & 2.105 .30 & 2.518 .11 \\
\hline 7. Tekstil & 1.979.30 & 2.917 .40 & 4.075 .35 \\
\hline
\end{tabular}

Sumber : Biro Pusat Statistik

Pada tabel di atas menunjukkan bahwa sumbangan devisa dari eksportekstil ini tahun 1991 sudahmencapai US $\$ 4075,35$ juta atau sekitar Rp 8,5 trilyun (bandingkan untuk membayar gaji dan pensiun pegawai pemerintah tahun 1990/1991 hanya Rp 5,57 trilyun). Perannya dalam menyumbang devisa bagi negara ini cenderung semakin besar. Sangat mungkin dalam waktu dekat ini ekspor tekstil tersebut akan melampaui tahun 1988-1992 mencapai 20,1\%, sedangkan kain tekstil dan benang tenun sebesar 17,9\% (lihat Trade and Management Institute, 1993, atau Kompas, 23/8/ 1993).

Secara lebih rinci perkembangan ekspor tekstil ini dibandingkan dengan perkembangan komoditi ekspor lainnya dapat dilihat pada Tabel berikut ini. 

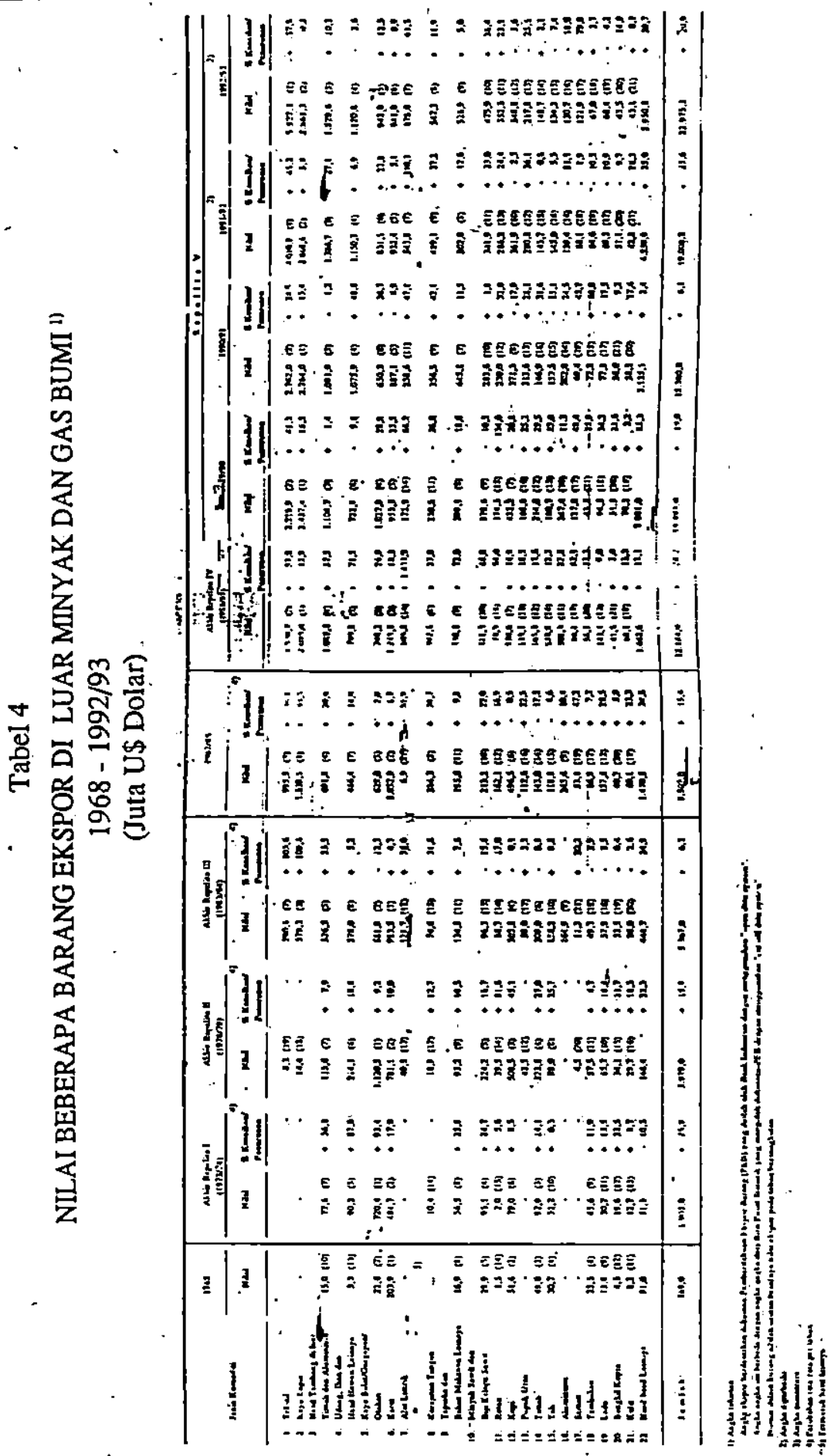

Dalam tabel tersebut ditunjukkan Repelita II namun jumlahnya masih sangat bahwa ekspor tekstil ini mulai sejak akhir kecil. Perkembangan yang pesat terjadi 
dalam lima tahun terakhir ini, yang meningkat dari hanya US\$996 juta tahun $1987 / 1998$ menjadi US $\$ 5527$ tahun 1992/ 1993 atau meningkat 5,5 kali lipat.

Meningkatnya ekspor tekstil ini menggambarkan bahwa dayasaing produk ini di pasardunia cukup kuat. Dayasaing ini juga diperkuat oleh adanya beberapa fasilitas yang diberikan oleh beberapa negara maju, yang memberikan potongan tarif bea masuk atas produk ini melalui fasilitas GSP (Generalized System of Preferences). Namun demikian pada masa yang akan datang masalah dayasaing ini m enjadi sangat penting untuk mendapatkan perhatian. Sebab negara-negara berkembang maupun negara-negara industri baru juga banyak yang mengandalkan komoditi tekstil sebagai salah satu eksporutamanya serta munculnya negara-negara pesaing baru seperti Cina di pasarinternasional. Disamping itu, fasilitasfasilitas yang memberikan kemudahan bagi produk tekstil ke negara maju serta pembatasan-pembatasan dalam bentuk kuota yang dibentang negara tujuan ekspor kita, akan merupakan kendala yang tidak kecil dalam mendorong ekspor tekstil ini.

Dalam hal kuota yang diberikan negara maju, sekarang ini memang masih meningkat dari tahun ke tahun. Namun demikian peningkatankuota tersebut masih lebih rendah dibandingkan peningkatan produksi dalam negeri. Dengan demikian produsen tekstil dipaksa untuk dapat mencari pasar-pasar baru agar tidak terjadi kelebihan produksinya.

Olehkarena itu peningkatan efisiensi menjadi sangat penting agar masuknya barang-barang ekspor kita, khususnya tekstil ini, bukan karena fasilitas yang diberikan oleh negara maju melainkan karena derajad kompetisinya yang tinggi.
Di samping itu, Indonesia perlu pula menganggap negara-negara non-kuota untuk meningkatkan ekspor tekstil ini. Negara-negara ini, seperti Timur Tengah ataupun sesama negara berkembang lainnya, merupakan pasar yang cukup potensial untuk dijadikan negara tujuan ekspor bagi komoditi tekstil ini. Ini memang tidak mudah karena harus bersaing secara bebas, sehingga masalah kualitas dan harga serta kemampuan untuk memelihara jaringan pemasaran menjadi sangat berperan dan perlu mendapatkan perhatian produsen.

Masalah diversifikasi tujuan ekspor ini sangat penting bagi kita mengingat negara tujuan ekspor tekstil kita masih terbatas pada sedikit negara, khususnya negara maju seperti Amerika Serikat, MEE, dan ke Singapura yang mere-ekspornya ke negara lain.

\section{Penutup}

Demikianlah beberapa catatan tentang beberapa aspek ekonomi dalam industri pertekstilan kita, khususnya yang berkaitan dengan masalah sumbangannya terhadap ekspor dan tantangan yang dihadapi pada masa depan. Secara singkat, dari uraian di atas, dapat dikatakan bahwa perkembangan industri tekstil ini sangat pesat. Industri tekstil juga sudah memberikan kontribusi yang cukup besar dalam menyumbang terhadap PDB, ekspor dan devisa, maupun kesempatan kerja. Namun demikian pada tahun-tahun mendatang industri ini akan menghadapi persoalan yang cukup berat yang berkaitan untuk dapat mempertahankan laju pertumbuhan yang tinggi. Ini mengingat pasar dalam negeri yang terbatas serta kian ketatnya persaingan di pasar dunia. 


\section{LAMPIRAN :}

\section{- GRAFIK}

PRODUKSI TEKSTIL FTEKSTIL LEAMBARA:

1968 - 1992/93

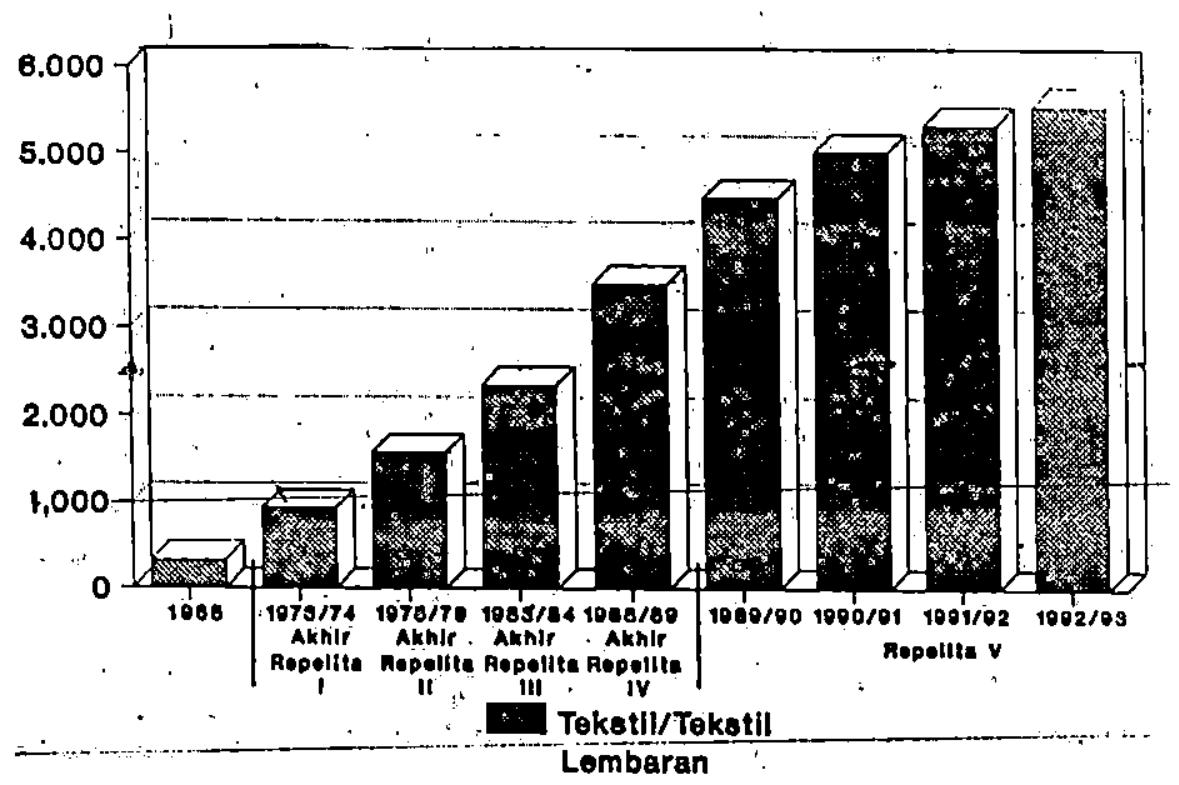


NGAN NILAI EKSPOR (F.O.B).

1968 - 1992/93

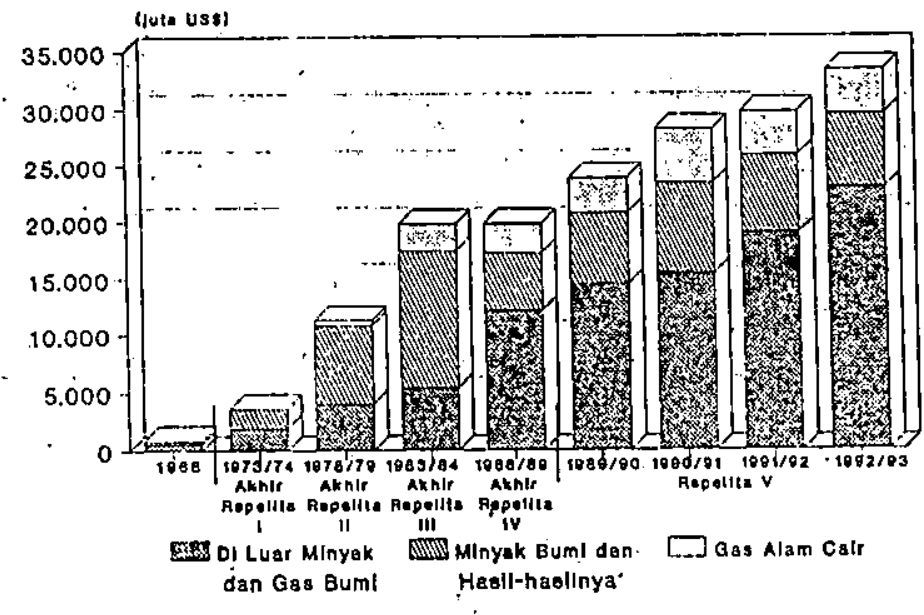

GRAFIK $V^{\prime}-2$

PERKEMBSANGAN NILAI IMPOR (F.O.B),

$1968-1992 / 93$

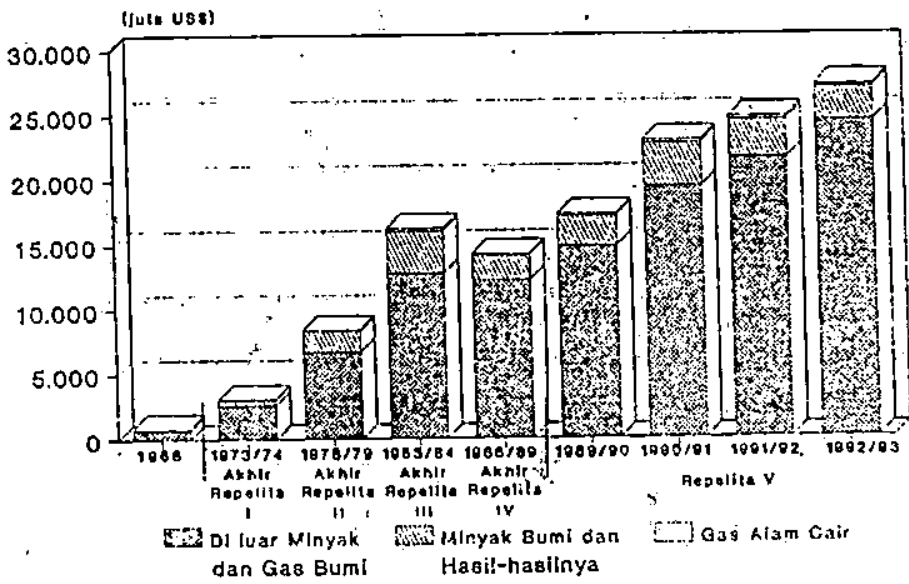

